\title{
The importance of education for humans
}

\author{
Ahmad Zuhdi ${ }^{{ }^{*}}$, Firman Firman1 ${ }^{1}$, Riska Ahmad ${ }^{1}$ \\ ${ }^{1}$ Pasca Sarjana Bimbingan dan Konseling, Universitas Negeri Padang, Indonesia \\ *) Correspondence: ahmadzuhdijuli25@gmail.com
}

\begin{abstract}
Humans are intelligent creatures and are endowed with various abilities. In essence, humans are creatures that have two roles, namely as individual beings and also as social beings. Humans are individual beings consisting of physical and spiritual elements created by God which cannot be separated. To achieve human nature as intelligent beings, education is needed. Education means an effort to develop the innate potential both physically and spiritually in humans according to the values that exist in society and culture. Therefore, researchers conducted a literature review on humans and education. The research method uses literature study. The research findings reveal that between humans and education is an inseparable unity.
\end{abstract}

Keywords: Education, humans

Article History: Received on 20/01/2021; Revised on 25/01/2021; Accepted on 17/02/2021; Published Online: 19/02/2021.

\section{INTRODUCTION} distribution, and reproduction in any medium, provided the original work is properly cited. (C2021 by author.

Istilah manusia bersumber dari kata homo dalam bahasa Latin, manu dari bahasa Sansekerta atau kata mens dari kata Latin yang bermakna berpikir, memiliki akal budi, makhluk yang berbeda dari makhluk lainnya (Saepul, 2006), makhluk yang lebih unggul daripada binatang (Muthahhari, 2002). Makhluk yang memiliki potensi untuk berkembang sesuai dengan hakekat penciptaannya (Syarif, 2017). Manusia secara hakekat merupakan ciptaan Tuhan yang individualis dan makhluk sosial. Disamping sebagai makhluk yang individualis, manusia juga diciptakan Tuhan sebagai makhluk sosial. Sebagai ciptaan Tuhan yang bersifat individualis. Manusia diciptakan oleh Tuhan atas unsur fisik dan psikis yang tidak boleh dipisahkan satu dengan lainnya. Jiwa dan ragalah yang menjadikan individu sebagai suatu diri yang utuh. Manusia dikategorikan dalam istilah homo sapiens dalam bahasa Latin yaitu makhluk primata bagian dari mamalia yang memiliki akal untuk berfikir dan dapat dikembangkan, untuk mengoptimalkan fitrah manusia tersebut maka dibutuhkannya pendidikan. Secara hakikat, karakteristik, potensi-potensi yang dimiliki serta kemampuan mengoptimalkan potensi diri merupakan hal yang membedakan manusia dengan makhluk Tuhan lainnya (Siti Khasinah, 2013). Menurut KBBI manusia merupakan ciptaan Tuhan yang memiliki akal dan kepribadian ke arah yang baik serta mampu menguasai makhluk lain.

Dalam Undang-Undang No. 20 Tahun 2003 telah dinyatakan bahwa pendidikan merupakan upaya terencana dan dilakukan secara sadar untuk menjadikan kegiatan belajar menjadi menyenangkan merangsang supaya peserta didik berperan aktif untuk 
mengoptimalkan potensi yang dimiliki agar menjadi pribadi yang religius, mampu mengendalikan diri, berkepribadian baik, cerdas dan berakhlak mulia, dan terampil, dalam kehidupan bermasyarakat, dan bernegara. Pendidikan juga berarti memberikan pelatihan dalam upaya untuk merubah sikap dan tingkah laku dalam proses mendewaskan manusia (Yuli Sectio, 2013).

Pendidikan berarti upaya untuk menumbuhkembangkan kemampuan-kemampuan bawaan baik kemampuan fisik maupun psikis selaras dengan nilai, budaya dan norma yang ada didalam masyarakat. Upaya dalam menanamkan nilai serta norma yang diwariskan kepada generasi selanjutnya untuk dioptimalkan dan diimplementasikan dalam kehidupan sehari-hari, menjadikan pendidikan menjadi wadah untuk melestarikan hidupnya.

Pembahasan materi dalam kajian ini hanya berfokus pada manusia dan kaitannya dengan pendidikan. Pemaparan singkat mengenai teori dan konsep dasar manusia dan pendidikan ini diharapkan dapat menjadi bahan informasi serta menambah refrensi pengetahuan bagi para pembaca.

\section{METHOD}

Penelitian ini menggunakan studi kepustakaan. Studi kepustakaan merupakan suatu metode penelitian hyang lebih menitik beratkan dan membatasi kegiatannya hanya pada bahan-bahan perpustakaan tampa perlu untuk melakukan riset lapangan (Zed, 2008). Penelitian ini dilakukan dengan mengumpulkan data-data yang relevan, membaca, dan mengkaji literatur yang relevan dan pada akhirnya merumuskan suatu kesimpulan.

\section{RESULT AND DISCUSSION}

\section{Konsep Manusia dan Haknya}

Istilah manusia bersumber dari kata homo dalam bahasa Latin, manu dari bahasa Sansekerta atau mens dalam bahasa Latin yang bermakna manusia adalah makhluk berpikir dan berakal budi. Manusia secara bahasa berarti ciptaan yang mempunyai akal budi serta mampu untuk menguasai lingkungannya, oleh karena itu manusia lebih tinggi derajatnya dan lebih berhak mendapatkan penghormatan (Kurniawati, 2018), makhluk yang memiliki akal dan nafsu (Afrida, 2018). Pada hakekatnya, manusia adalah makhluk monodualis. Monodualis bermakna bahwa manusia disamping sebagai ciptaan Tuhan yang individualis, manusia juga merupakan makhluk sosial. Sebagai ciptaan Tuhan yang bersifat individualis, ia diciptakan atas unsur jasmaniah dan rohani (jiwa) yang tidak bisa dipisahkan. Dapat dipahami manusia sebagai makhluk sosial ia merupakan individu yang tidak mampu untuk hidup sendiri, ia membutuhkan orang lain dalam kehidupannya.

Manusia adalah hasil ciptaan Tuhan yang memiliki kesempurnaan. Karena manusia diciptakan dilengkapi dengan akal yang menjadi pembeda manusia dengan makhluk lainnya. Kesempurnaan ciptaan yang terdapat pada diri manusia menjadikan ia dituntut atas tanggung jawabnya sebagai pemimpin dalam kehidupannya. Manusia adalah makhluk yang mempunyai rasa sadar (consciousness) serta kesadaran akan diri (self- 
awarness). Oleh sebab itu, manusia merupakan makhluk yang sadar akan eksistensinya, ia dapat menemukan bahwa dirinya berbeda dengan semua yang ada di luar dirinya (objek). Manusia tidak hanya dapat berpikir mengenai diri serta lingkungannya, namun juga sadar tentang pemikirannya sendiri. Meskipun ia sadar akan perbedaannya dengan alam akan tetapi dalam pembahasan alam semesta secara keseluruhan manusia adalah salah satu unsur dari alam semesta itu sendiri. Oleh karena itu, manusia tidak hanya bertanya mengenai asal-usul alam semesta tempat ia berada, manusia juga mempertanyakan eksistensi keberadaan dirinya sendiri di alam semesta. Hakekat manusia adalah pokok dari manusia seutuhnya, yang di dalamnya terdapat jawaban mengapa ia diciptakan sampai pada perjalanannya kembali ke hadapan Tuhan (Prayitno, 2009).

Manusia memiliki fitrah selalu cenderung kepada kebenaran yang dianugerahkan oleh Tuhan Sang Maha Pencipta. Artinya bahwa manusia dilahirkan dalam berbagai macam potensi yang siap untuk dikembangkan kearah yang positif. Akal yang dianugerahkan kepada manusia menandakan bahwa mausia adalah makhluk yang mendayagunakan akalnya, makhluk yang selalu berkeinginan untuk tahu siapa Tuhannya, serta memiliki kecenderungan untuk beragama (Ahnan dan Syafa, 1994), maka dari itu dapat dipahami bahwa manusia adalah makhluk yang dinamis, ia diberikan daya untuk mampu merubah dirinya ke arah yang lebih baik.

Manusia secara hakekat merupakan ciptaan Tuhan yang bertugas menjadi pemimpin dalam kehidupannya, memiliki potensi atau fitrah untuk berkembang dan memiliki karakter serta memiliki kecenderungan positif kearah yang baik. Manusia disebut sebagai homo sapiens dalam Bahasa Latin yang bermakna golongan yang memiliki akal pikiran dan otak berkemampuan tinggi. Manusia merupakan makhluk yang bertanya, ia memiliki keinginan untuk tahu me174444ngenai segala hal. Karena hasrat keingintahuannya manusia bukan hanya menanyakan mengenai hal-hal yang di luar dirinya, namun juga bertanya mengenai diri secara pribadi. Dalam perkembangan ilmu pengetahuan, manusia senantiasa berusaha mengetahui dirinya secara pribadi yang dikaji melalui berbagai macam pendekatan ilmu pengetahuan serta melalui berbagai macam sudut pandang keilmuan (Mudyahardjo, 2012), hal tersebut menggambarkan bahwa manusia berbeda dengan makhluk hidup lainnya, ia senantiasa berpikir dalam segala hal untuk menjadikan dirinya manusia seutuhnya.

Menurut golongan eksistensialis (dalam Tirta Rahardja dan La Sulo, 2010), hakekat manusia mencakup:

1. Kemampuan menyadari diri: Manusia sadar dirinya memiliki perbedaan dengan makhluk lain. Adanya jarak terhadap hal di luar dirinya menjadikan manusia terdorong untuk mengembangkan aspek sosialnya dan rasa keingintahuannya. Sedangkan adanya batasan terhadap diri pribadi menjadi pendorong bagi manusia untuk mengembangkan aspek individualitasnya untuk memahami hakikat penciptaannya sebagai manusia.

2. Kemampuan bereksistensi: manusia adalah makhluk yang berpikir, dengan kemampuannya tersebut ia mampu menembus dan melewati batasan yang menjadikan dirinya terbelenggu. Kemampuan ini tidak dapat diabatasi oleh ruang dan waktu, ia dapat menerobos ke masa depan serta ke masa lalu sekalipun. Kemampuan 
tersebut yang dinamakan kemampuan bereksistensi. Kemampuan ini menjadikan manusia memiliki kebebasan dalam mengembangkan dirinya.

3. Kata hati: adalah kemampuan menghasilkan keputusan-keputusan yang baik maupun buruk yang dimiliki oleh manusia untuk menjadi manusia seutuhnya. Orang yang memiliki kata hati yang baik akan mampu mengambil keputusan yang tepat penuh dengan pertimbangan yang tidak hanya menguntungkan dirinya sendiri namun juga menyenangkan bagi orang lain. Manusia adalah makhluk yang berpikir, ia akan dapat memahami konsekuensi baik dan buruk dari keputusan yang dibuatnya sebagai manusia.

4. Tanggung jawab: merupakan kesiapan untuk menerima konsekuensi dari hal-hal yang dilakukan. Terdapat berbagai macam perwujudan dari tanggung jawab seperti tanggung jawab terhadap diri pribadi, lingkungan dan Sang Maha Pencipta. Penyesalan yang mendalam atas suatu kesalahan yang dilakukan di masa lampau dan tidak mengulangi dimasa mendatang merupakan bentuk perwujudan tanggung jawab kepada diri secara pribadi. Tanggung jawab terhadap lingkungan berarti siap melaksanakan norma-norma sosial dan bersedia menerima konsekuensi apabila melanggar norma sosial yang telah ditetapkan bersama. Tanggung jawab kepada Tuhan bermakna menjalankan tuntutan agama secara baik sesuai dengan tuntunan syariatnya dan bersedia menerima konsekuensi atas perbuatan yang bertentangan dengan ajaran-ajaran agama.

5. Rasa kebebasan: kebebasan dalam artian manusia bebas berbuat sesuai dengan tuntutan kodratnya. Bisa melakukan berbagai macam hal sepanjang perbuatan tersebut tidak menentang tuntutan kodrati manusia.

6. Kewajiban dan hak: merupakan dua hal yang melekat pada diri manusia sebagai perwujudan bagi manusia sebagai makhluk sosial. Unsur hak dan kewajiban tidak dapat dipisahkan karena saling berkaitan. Hak tidak akan terpenuhi apabila kewajiban tidak dilksanakan, dan begitupun sebaliknya. Pada kenyataannya, hak sering diartikan sebagai hal yang menimbulkan rasa senang dan menguntungkan, dan kewajiban diartikan sebagai sesuatu yang membuat beban. Faktanya adalah kewajiban merupakan keniscayaan pada manusia, selama seseorang menyatakan dirinya manusia seutuhnya, maka ia wajib menjalani kewajibannya menjadi makhluk sosial.

7. Kemampuan menghayati kebahagiaan: memahami bahwa kebahagiaan terletak pada keheningan jiwa dalam menghayati segala sesuatu, serta mendefenisikan kebahagiaan itu terletak pada usaha yang dilakukan, kesesuaian dengan norma-norma dan takdir yang telah ditentukan Tuhan.

Dalam kenyataannya, sesama manusia memiliki banyak sekali perbedaan, baik berupa penampilan fisik, strata sosial dalam masayarakat, adat dan kebiasaan sehari-hari maupun tingkat pengetahuannya. Akan tetapi dibalik berbagai macam perbedaan tersebut terdapat satu hal yang menyatakan bahwa manusia adalah sama, yaitu semua manusia adalah manusia yang diciptakan oleh Tuhan dengan potensi kebaikan. Hakikat manusia adalah persamaan ciri dasar dari setiap manusia itu sendiri. Hakikat manusia dengan kata lain dapat diartikan sebagai seperangkat konsep mengenai "sesuatu yang olehnya "manusia menjadi apa yang terwujud, "sesuatu yang olehnya"manusia mempunyai ciri yang khas, "sesuatu yang olehnya" ia merupakan sebuah nilai yang unik, yang memiliki suatu martabat khusus (Wahyudin, 2008), yang artinya bahwa manusia 
adalah individu yang bertanggung jawab atas kehidupannya sendiri, memiliki kedudukan yang tinggi dan berbeda dari makhluk lainnya.

Tirtahardja dan La Sulo (2010) membagi hakikat manusia ke dalam empat macam dimensi, yaitu:

\section{Dimensi individual}

Bahwa manusia itu dilahirkan dalam keadaan unik dan memiliki ciri khas masingmasing. Potensi yang dibawa dari lahirpun berbeda-beda yang siap untuk dikembangkan yang akan membedakannya dengan anak yang lain, hal inilah yang dinamakan dengan individualitas. Dengan adanya sifat individualitas menjadikan setiap manusia mempunyai kehendak yang berbeda, daya tahan tubuh yang berbeda, keinginan dan kecenderungan yang berbeda, sudut pandang yang berbeda, berbeda dalam cita-cita yang ingin dicapai, berbeda dlam kemampuan intelektual dan sebagainya. Maka dari itu setiap manusia mempunyai ciri karakteristik diri yang unik berbeda dengan manusia lainnya.

2. Dimensi social. Manusia selalu melakukan interaksi dan komunikasi dengan individu lainnya dalam kehidupan sehari-hari. Manusia akan mampu berperan sebagai manusia jika ia berada diantara manusia. Manusia tidak akan mampu hidup mengembangkan potensi kemanusiaannya jika ia berada ditempat yang terasing dengan manusia lainnya. Karena seseorang akan dapat mengoptimalkan karakteristik individunya dalam masyarakat sosial. Didalam kehidupan bermasyarakat individu dapat mengasah hobinya, mengoptimalkan usaha mencapai cita-citanya dalam berinteraksi dengan anggota masyarakat lainnya.

3. Dimensi kesusialaan. Manusia merupakan makhluk yang mempunyai nilai dan martabat yang tinggi, oleh karena itu manusia dinamakan sebagai makhluk susila (Rahmi Damis, 2014). Menurut Drijarkoro, manusia susila adalah makhluk yang memiliki nilai-nilai, penghayatan, serta mengimplementasikan nilai-nilai baik didalam kehidupannya sehari-hari. Dengan menyadari dan memahami nilai-nilai manusia akan dapat berbuat dan bertindak sesuai dengan fitrahnya sebagai manusia seutuhnya.

4. Dimensi keberagamaan. Secara kodrati ia merupakan makhluk beragama yang dianugerahi potensi kebaikan serta potensi beragama, ia mempercayai dan menyadari adanya kekuatan maha dahsyat yang menguasai segala sesuatu. Hidup dalam agama merupakan suatu kebutuhan manusia. Agama merupakan tempat bertopang dan pemberi petunjuk bagi manusia dalam menjalani kehidupannya. Manusia memerlukan agama demi keselamatan hidupnya.

Dimensi-dimensi tersebut di atas merupakan dimensi yang terdapat dalam diri setiap manusia, keempat dimensi tersebut harus dikembangkan secara optimal, untuk menjamin optimalnya perkembangan dimensi-dimensi tersebut dibutuhkannya hak-hak yang dapat menjamin kehidupannya yang disebut hak asasi manusia. Setiap manusia yang terlahir di dunia secara kodrati telah mendapatkan hak untuk hidup oleh Tuhan YME. Hak asasi manusia secara inheren telah ada dalam ajaran agama islam yang dimuat didalam alQuran dan Sunnah (Ahmad Mukri, 2015). Menurut bahasa, hak asasi manusia bisa dimaknai sebagai hak-hak yang melekat pada individu karena lahirnya sebagai manusia. Hak-hak ini merupakan hasil dari buah pikiran yang mendalam dengan tujuan untuk memelihara harkat dan martabat seorang individu dalam hidupnya. HAM dengan 
kata lain bisa dimaknai sebagai hak-hak yang menyatu pada diri individu sehingga menjadikan ia diakui eksistensinya tanpa adanya rasisme dan diskriminasi.

Berdasarkan Pasal 1 Undang-Undang (UU) Nomor 39 Tahun 1999, HAM merupakan sekumpulan hak yang menyatu pada hakikat dan keberadaan manusia sebagai makhluk Tuhan Yang Maha Esa dan merupakan anugerah-Nya yang wajib dihormati, dijunjung tinggi, dan dilindungi oleh Negara, hukum, pemerintah, dan setiap orang demi kehormatan serta perlindungan harkat dan martabat manusia (Suparman Usman, 2008), maka dari itu setiap manusia memperoleh jaminan untuk hidup dan mengembangkan dimensi kemanusiaannya.

Tegasnya, HAM merupakan hak yang menyatu pada individu, tanpa adanya hak tersebut manusia tidak bisa hidup sebagai manusia, sifat haknya tidak bisa dihapuskan atau dikurangkan oleh siapapun. Sebagai sesama manusia dan warga negara yang baik kita wajib menjungjung tinggi nilai-nilai HAM. Ada beberapa macam HAM, salah satu diantaranya adalah Social Culture Right atau hak asasi sosial budaya yang meliputi:

1. Menentukan, memilih dan memperoleh pendidikan

2. Memperoleh pengajaran

3. Mengembangkan budaya yang sesuai dengan bakat dan minat.

Salah satu hak dasar dalam sosial budaya di atas adalah mendapatkan pendidikan. Hak atas pendidikan (HAP) tidak bisa dipisahkan dari pembahasan mengenai HAM secara keseluruhan. Pada tema akademik, hak asasi manusia sering dibagi ke dalam beberapa bagian, yakni HAM Sipil dan Politik dan HAM Ekonomi, Sosial, dan Budaya. Secara khusus, dalam UUD 1945 telah terdapat konsep hak asasi manusia dalam bidang pendidikan yang menyatakan bahwa mencerdaskan kehidupan bangsa merupakan tugas pemerintah Indonesia (Bagir Manan, 2001).

Secara umum, HAP sebagai kewajiban negara sebagai suatu upaya pemenuhan HAM dalam UUD 1945 sudah semakin ditegaskan. Dalam Pasal 31 UUD 1945 baik sebelum ataupun setelah mendapatkan perubahan telah dilakukannya pengaturan dan jaminan HAP, juga dipertegas dan diperjelas secara khusus ketika terjadinya perubahan kedua UUD 1945 pada tahun 2000. Materi muatan HAM dimasukkan secara menyeluruh mulai dari Pasal 28A sampai dengan Pasal 28J dalam perubahan kedua ini. Dalam Pasal 28C ayat (1) dan Pasal 28E ayat (1) UUD 1945 secara khusus ditegaskan pengaturan dan jaminan terkait dengan hak atas pendidikan.

Proses memanusiakan manusia atau humanisasi merupakan makna dari pendidikan. Pendidikan secara ekspilisit mengajarkan untuk menghormati sepenuhnya HAM. Siswa tidak bisa disamakan dengan robot yang dapat dikontrol sesuai keinginan tenaga pendidik, peserta didik merupakan individu yang harus diberikan bantuan dan diberikan perhatian dalam setiap tahap-tahap perkembangannya agar mampu menjadi individu yang berdiri sendiri dan mampu berpikir secara kritis, oleh karena itu pendidikan bukan hanya mengoptimalkan potensi manusia yang berbeda dengan makhluk lainnya, namun lebih daripada itu untuk menghasilkan manusia seutuhnya yang sesuai dengan hakikat penciptaannya (Ab Marisyah, Firman, Rusdinal, 2019). Kemampuan berpikir kritis yang diharapkan pada siswa akan dapat diwujudkan melalui proses pembelajaran yang didalamnya secara tidak langsung mengasah kemampuan 
berpikir peserta didik serta kemampuan untuk menyampaikan konsep ataupun gagasan yang cemerlang (Dwi Wulan Suci, Firman, Neviyarni, 2019). Dapat dipahami bahwa manusia atau dalam hal ini peserta didik memerlukan pendidikan sebagai sarana untuk mengoptimalkan pendayaguanaan akal pikiran untuk menjadikan ia sebagai makhluk yang berakal budi.

Setiap orang mempunyai hak untuk mengoptimalkan kemampuan diri dengan cara memenuhi kebutuhan dasarnya, memiliki hak untuk memperoleh pendidikan dan mendapatkan dampak positif dari perkembangan IPTEK, seni dan budaya, dalam rangka optimalisasi kualitas hidup demi kesejahteraan umat manusia merupakan kandungan penegasan hak dari Pasal 28C ayat (1) UUD 1945. Dalam Pasal 28E ayat (1) UUD 1945 dinyatakan bahwa setiap orang diberi kebebasan untuk memeluk dan menjalankan ajaran agamanya,bebas menentukan pendidikan dan pengajaran, kebebasan dalam menentukan pekerjaan, menentukan kewarganegaraan yang diinginkan, bebas menentukan tempat tinggal di wilayah negara dan meninggalkannya, serta berhak kembali. Dapat dipahami bahwa manusia adalah makhluk ciptaan Tuhan yang sempurna yang dianugerahi potensi-potensi positif untuk dikembangkan sesuai dengan hakekatnya sebagai manusia serta memperoleh dua jaminan utama yaitu memiliki hak untuk memperoleh pendidikan dan berhak secara bebas untuk menentukan pendidikan dan pengajaran yang diinginkan.

\section{Konsep Dasar Pendidikan}

Dalam Undang-Undang No. 20 Tahun 2003 pendidikan dimaknai sebagai upaya yang dilakukan secara sadar dan terencana yang bertujuan untuk menciptakan kegiatan pembelajaran dimana peserta didik dapat secara aktif mengoptimalkan potensi yang dimilikinya agar terciptanya pribadi yang religius, dapat mengendalikan diri, berkepribadian baik, cerdas, dan berakhlak mulia, serta terampil dalam kehidupan sehari-hari, dalam masyarakat, bangsa dan negara. Pendidikan merupakan humanisasi, yaitu berupa usaha memanusiakan manusia dalam konteks memberikan bantuan kepada manusia atau peserta didik supaya dapat hidup selaras dengan fitrah kemanusiaannya, mampu menjadi pribadi yang mantap merupakan sifat dari pendidikan (Wahyudin, 2008).

Mahmud Yunus dan Martinus Jan Langeveld mendefenisikan pendidikan sebagai bagian upaya yang dilakukan secara sengaja bertujuan agar memberikan pengaruh serta bantuan terhadap peserta didik dengan tujuan untuk mengoptimalkan kemampuan intelektual, fisik dan akhlak (rohani) yang nantinya dapat membawa peserta didik kepada maksud dan cita-cita yang diinginkannya, serta mendapatkan hidup yang bahagia dan segala hal yang diperbuatnya mampu memberikan manfaat bagi dirinya sendiri, lingkungan, agama, dan bangsa. Ki Hajar Dewantara sebagai bapak pendidikan nasional Indonesia menyatakan bahwa pendidikan adalah suatu tuntutan dalam berlangsungnya tumbuh kembang anak, maksud dari pendidikan tersebut yakni mengarahkan seluruh fitrah yang terdapat pada peserta didik supaya mereka mampu memperoleh keselamatan dan kebahagiaan (Haryanto, 2012).

Menurut Heidjrachman dan Husnan (1997) menyatakan bahwa pendidikan merupakan bentuk usaha bertujuan meningkatkan pengetahuaan seseorang mengenai sesuatu dimana termuat di dalamnya pengoptimalan penguasaan teori dan praktik, kemampuan mengambil keputusan dan menemukan solusi dari problema yang dialami 
dalam usaha memperoleh apa yang menjadi tujuannya, baik persoalan dalam hal dalam dunia pendidikan maupun persoalan-persoalan yang muncul dalam kehidupan seharihari. Dapat dipahami bahwa pendidikan bermakna sebagai bentuk upaya manusia dalam menumbuhkembangkan potensi-potensi pembawaan baik jasmani maupun rohani dari lahir selaras dengan nilai-nilai yang ada didalam masyarakat dan kebudayaan. Seorang "calon" manusia akan dapat menjadi manusia seutuhnya dapat diwujudkan melalui pendidikan yang dilakukan oleh manusia lainnya untuk menerima sesuatu yang baru.

\section{Tujuan Pendidikan}

Pendidikan bertujuan agar merangkum segala sesuatu yang baik dan positif yang menguntungkan bagi diri dan orang untuk diimplementasikan dalam kehidupan, dengan demikian terdapat dua fungsi dalam tujuan pendidikan: pertama, memberikan arah pada proses kegiatan pendidikan yang dilakukan dan kedua, sebagai bahan acuan ataupun target yang akan diperoleh melalui proses pendidikan tersebut (Elfachmi, 2016).

Secara umum tujuan kegiatan pendidikan adalah mengantarkan siswa kearah kedewasaan yang optimal. Maksudnya, mengantarkan peserta didik supaya bisa mandiri dalam kehidupan di tengah-tengah masyarakat. Beberapa pokok pembahasan tujuan pendidikan yang lebih luas, yaitu:

1. Tujuan pendidikan nasional

Secara sadar bahwa seluruh kehiatan pendidikan diarahkan dengan tujuan untuk dapat melahirkan atau mencetak manusia-manusia berpendidikan untuk kepentingan bangsa agar terjadinya kemajuan dalam pembangunan negara. Karena pembangunan merupakan suatu proses yang berkembang, dengan kata lain sebagai suatu proses perubahan yang meningkat dan terus bergerak maju, maka dari itu pendidikan diharapkan mampu membentuk atau melahirkan manusia-manusia yang mampu mengikuti dan memberikan kontribusi dalam proses perkembangan negara tersebut serta tidak melepaskan diri dari dasar-dasar budaya dan kepentingan Negara. Tujuan pendidikan Indonesia mempunyai landasan yang kokoh berlandaskan falsafah bangsa yaitu filsafat pancasila, filsfat pancasila merupakan pedoman inti dalam pendidikan, melalui upaya-upaya pendidikan dalam keluarga inti, masyarakat, dan pendidikanpendidikan formal. Pendidikan juga merupakan wadah bagi negara untuk melahirkan tenaga-tenaga ahli dibidangnya masing-masing yang akan membantu menanggulangi problema yang dialami oleh negara itu sendiri (I Wayan, 2019).

2. Tujuan Institusional

Merupakan suatu kebijakan mengenai pola kognitif, afektif dan psikomotor yang harus dimiliki oleh lulusan suatu lembaga pendidikan. Perumusan tujuan bagi tiaptiap lembaga pendidikan bisa mempunyai perbedaan, menyesuaikan terhadap fungsi dan tugas yang dibebankan oleh masing-masing lembaga yang bertujuan untuk menciptakan lulusan dengan kemampuan dan keterampilan secara spesifik yang dibutuhkan oleh lembaga itu sendiri, masyarakat dan Negara.

3. Tujuan kurikuler

Rumusan tujuan pendidikan kurikuler didasarkan pada kecakapan yang ingin diberikan kepada peserta didik. Tujuan ini berhubungan dengan bidang studi atau keterampilan yang diberikan kepada peserta didikik untuk mencapai target yang diinginkan dari bidang studi tersebut. 
4. Tujuan instruksional

Merupakan rumusan tujuan pendidkan secara terperinci yang wajib dikuasai oleh peserta didik ketika sudah menyelesaikan kegitan instruksional yang dimaksud dengan berhasil. Dan hasil yang telah didapat dalam pendidikan instruksional ini seyogyanya dapat dinilai secara nyata melalui tingkah laku peserta didik.

Danim (2010) menjelaskan mengenai beberapa tujuan pendidikan. Pertama, yaitu kegiatan optimalisasi bakat kognitif, afektif, dan psikomotor peserta didik. Kedua, sarana untuk mewariskan nilai-nilai budaya secar lintas generasi bertujuan untuk meningkatkan rasa nasionalisme serta menghindari kemungkinan tercabutnya akar nilai budaya dan kehidupan berbangsa dan bernegara pada generasi penerus. Ketiga, mengembangkan kemampuan penyesuaian diri siswa untuk menghadapi situasi perkembangan zaman yang terus berubah, seiring dengan perkembangan IPTEK. Keempat, mengoptimalkan dan meningkatkan tanggung jawab moral peserta didik, yakni kemampuan dalam membedakan mana yang baik dan mana yang buruk, dengan semangat atau keyakinan untuk mengimplementasikannya dengan baik. Pendidikan yang berkualitas bertujuan untuk menciptakan SDM yang berkualitas agar tercapainya cita-cita bangsa (Dapip Sahroni, 2017).

Pendidikan memiliki urgensi sebagai wadah dalam menyiapkan siswa menyongsong dunia di masa mendatang. Guru wajib memiliki kompetensi dalam menciptakan proses dan lingkungan belajar yang menunjang proses pendidikan dan mampu untuk memahami karakteristik pribadi peserta didik yang berbeda-beda. Tenaga pendidik bertanggung jawab sepenuhnya terhadap proses pendidikan dalam rangka mengoptimalkan potensi siswa (Elke Maisyarah, Firman, 2019). Pendidikan juga berfungsi menciptakan manusia yang berkarakter,karakter merupakan bagian penting yang ada didalam diri manusia (Murni Eva, 2015).

Tujuan pendidikan akan dapat diwujudkan apabila ranah kognitif, afektif dan psikomotor peserta didik mampu berkembang secara optimal, ketiga ranah tersebut mempunyai pengaruh yang besar terhadap keberhasilan proses pendidikan, sinergi antara ketiga ranah tersebut akan memberikan manfaat yang positif baik terhadap diri peserta didik maupun lingkungan (Mufadal, Riska Ahmad, Ifdil, 2018). Pendidikan berupaya melahirkan manusia yang bermartabat dan berakhlak mulia serta menjadikan individu tersebut sebagai pribadi yang mandiri serta menjadi bagian dari masyarakat yang beradab (Saihu, 2019). Maknanya adalah pendidikan merupakan bagian penting untuk menjadikan manusia seutuhnya.

Dapat dipahami bahwa pendidikan adalah suatu rangkaian proses yang mempunyai tujuan. Fungsi dari tujuan adalah sebagai dasar bagi pendidikan tersebut dilaksanakan. Dengan katalain tujuan pendidikan adalah salah satu hal yang urgen dalam rangkaian pendidikan, hal yang ingin dicapai dalam pendidikan bukan hanya akan memberikan arah kemana harus menuju, tetapi juga bertujuan untuk menentukan kesesuaian dalam pememilihan materi, cara, serta instrumen pengevaluasi dalam kegiatan yang dilakukan.

\section{Faktor-faktor Pendidikan}

Faktor-faktor yang diperlukan kehadirannya dalam pelaksanaan kegiatan pendidikan diantaranya: 
1. Tujuan pendidikan, tujuan yang akan diperoleh dalam suatu pendidikan menentukan kesesuaian kurikulum dan isi pendidikan yang diberikan terhadap peserta didik, dengan adanya tujuan pendidikan juga akan mempengaruhi strategi penentuan teknik penyampaian pendidikan yang diaplikasikan untuk memberikan pembelajaran kepada peserta didik dalam usaha pencapaian tujuan pendidikan yang telah dirumuskan.

2. Pendidik, merupakan individu yang memiliki tanggung jawab memberikan bantuan kepada peserta didik dalam perkembangan fisik dan psikis, supaya mamapu memperoleh tingkat kedewasaan yang optimal. Pendidik merupakan manusia yang berkualitas yang akan mewujudkan kegiatan pendidikan yang melayani masyarakat (Epon Ningrum, 2016).

3. Peserta didik/siswa, tiap siswa mempunyai karakteristik pribadi yang unik. Kareana itu, mereka tidak bisa disamakan satu sama lain, pendidik wajib terampil dan berupaya untuk tahu terhadap karakteristik masing-masing siswanya supaya bantuan pendidikan yang diberikan sesuai dengan kebutuhan dan keadaan pembawaaan pribadi peserta didiknya.

4. Sarana Pendidikan, meurpakan segala sesuatu pendukung yang dapat dimanfaatkan dan digunakan oleh pendidik dalam usaha untuk membantu meraih tujuan pendidikan yang telah dirumuskan. Sarana pendidikan dianggap memiliki peranan penting bagi terciptanya pendidikan yang kondusif yang akan mendukung terwujudnya tujuan pendidikan.

5. Lingkungan, kegiatan pendidkan selalu dilakukan dalam suatu lingkungan tertenu, seperti lingkungan keluarga, lingkungan sekolah dan lingkungan masyarkat yang memberikan pengaruh positif kepada perkembangan siswa, maka seyogyanya untuk mencapai tujuan pendidikan secara optimal dan efisien, faktor lingkungan pendidikan juga harus diperhatikan.

Faktor-faktor pendidikan yang telah disebutkan di atas merupakan suatu kesatuan yang tidak dapat dipisahkan, antara faktor satu dan lainnya saling mendukung guna untuk terciptanya suatu kegiatan pendidikan dan tercapainya tujuan pendidikan yang dimaksud.

\section{Kaitan Manusia dan Pendidikan}

Manusia merupakan makhluk luhur dan paling mulia yang diciptakan oleh Tuhan Yang Maha Esa. Manusia mempunyai derajat dan hak-hak yang sama tampa terkecuali. Hak dan derajat manusia yang luhur tersebut merupakan anugerah dari Tuhan yang tidak bisa dihilangkan. Dengan demikian semua manusia dapat mengoptimalkan pribadinya sesuai dengan fitrah kemanusiaannya, salah satu caranya adalah melalui pendidikan. Pendidikan juga merupakan sebuah bentuk investasi non fisisk ataupun investasi sumber daya manusia (Hastarini Dwi, 2005). Pendidikan diperelukan untuk menjadikan manusia seutuhnya atau manusia tersebut wajib mendapatkan pendidikan, hal ini didukung dengan pernyataan Immanuel Kant dalam teori pendidikannya bahwa manusia akan menjadi manusia hanya nelalui proses pendidikan (Wahyudin, 2008).

Sederhananya pendidikan dinamakan sebagai suatu kegiatan memanusiakan manusia, Abdurrahman Shalih menyatakan bahwa manusia adalah bagian pokok dari proses pendidikan, maksudnya adalah bahwa manusia merupakan elemen inti dari suatu kegiatan pendidikan, artinya manusia memainkan dua peran yaitu sebagai obyek dan 
juga sekaligus sebagai pelaku pendidikan. Oleh karena itu seperti apapun pendidikan itu dirancang dan diformulasikan serta diimplementasikan harus selalu bersandar pada konsep mengenai hakekat dari manusia itu sendiri. Begitupun dalam hal perumusan dan pengembangan tujuan pendidikan, isi pendidikan, cara pendidikan diberikan, kurikulum yang dipakai, serta cara mengevaluasi pendidikan dan sebagainya harus selalu selaras pada filsafat tentang hakekat manusia itu sendiri. Manusia dan pendidikan tidak dapat dipisahkan, pendidikan merupakan bagian penting dari manusia dan merupakan suatu kebutuhan (Sigit Dwi, 2016) setiap aspek kehidupan manusia membutuhkan pendidikan (Anwar, 2015).

Dalam tujuan Pendidikan Nasional dinyatakan bahwa pendidikan bertujuan untuk menciptakan individu yang memiliki kualitas yang dijelaskan secara rinci dalam UU No. 2 tentang Sistem Pendidikan Nasional (Sisdiknas) dan Garis-garis Besar Haluan Negara (GBHN) 1993, yakni individu yang memiliki iman dan ketakwaan kepada Tuhan, memiliki rasa tanggung jawab yang tinggi, nasionalisme yang tinggi dan semangat patriotik, berkepribadian baik, memiliki etos kerja yang tinggi, profesional dalam menjalankan segala sesuatu, individu yang produktif serta inovatif, aktif, dan mempunyai pandangan visioner. Hal tersebut sejalan dengan arah pendidikan yang diinginkan sebagaimana terdapat dalam Undang-Undang Sistem Pendidikan Nasional (UUSPN) dan Peraturan Pemerintah (PP) No. 29 Tahun 1990.

Dengan demikian, manusia memiliki kebebasan untuk berupaya mengoptimalkan potensi-potensi yang dimilikinya. Dalam kehidupannya sehari-hari manusia membutuhkan manusia lainnya, ia tidak dapat hidup sendiri. Dalam interaksi itulah manusia diwajibkan memiliki suatu etika hidup bermasyarakat. Untuk menjadi manusia seutuhnya yang mampu hidup ditengah masyarakat dengan etika dan nilai-nilai yang sesuai bisa dicapai dengan kegiatan pendidikan. Pendidikan tidak hanya difokuskan untuk membina kepribadian manusia, pendidikan juga bertujuan untuk membina masyarakat. Masyarakat merupakan suatu bentuk manifestasi kehidupan secara bersamasama bagi individu. Dalam masyarakat terjalin relasi kehidupan sosial, komunikasi dan interaksi dalam masyarakat yang merupakan suatu tempat kehidupan manusia sekaligus tempat berlangsungnya keseluruhan proses perkembangan kehidupan. Untuk berkembang secara optimal dan utuh ditengah masyarakat maka individu memerlukan pendidikan sepanjang hidupnya.

\section{CONCLUSIONS}

Manusia merupakan makhluk ciptaan Tuhan Yang Maha Esa yang dianugerahi akal budi dan berbagai macam potensi untuk dikembangkan. Semenjak lahir ke-dunia manusia telah diberikan hak-hak kodrati yang tidak bisa diganggu oleh siapapun salah satu diantaranya adalah hak memperoleh pendidikan yang termuat didalam hak asasi sosial budaya dan dijamin oleh Undang-Undang. Pendidikan bertujuan untuk mengembangkan secara optimal potensi-potensi yang dimiliki oleh manusia agar ia menjadi manusia yang seutuhnya. Pendidikan bertujuan untuk memanusiakan manusia, maka dari itu antara manusia dan pendidikan merupakan suatu kesatuan yang tidak dapat dipisahkan. 


\section{REFERENCES}

Afrida, A. (2018). Hakikat Manusia dalam Perspektif Al-Quran. Al-Qisthu: Jurnal Kajian Ilmu-ilmu Hukum, 16(2), 54-59.

Ahnan, Maftuh \& Syafa, Ach.Zacky. (2001). Filsafat Manusia. Surabaya: Terbit Terang.

Aji, A. M. (2015). Hak dan Kewajiban Asasi Manusia Dalam Perspektif Islam. SALAM: Jurnal Sosial dan Budaya Syar-i, 2(2).

Anwar, M. (2015). Filsafat pendidikan. Kencana.

Anwar, S. (2006). Hakekat Manusia (Manusia Dimata Filosuf Dan Al-Qur'an Serta Kajian Tentang Inti Manusia). Jurnal Kajian Pendidikan Agama-Ta'lim Vol, 4(2-2006), 133.

Barseli, M., Ahmad, R., \& Ifdil, I. (2018). Hubungan stres akademik siswa dengan hasil belajar. Jurnal EDUCATIO: Jurnal Pendidikan Indonesia, 4(1), 40-47.

Damis, R. (2014). Falsafah Manusia Dalam Al-Qur'an. Jurnal Sipakalebbi, 1(3).

Danim, S. (2010). Perkembangan Peserta Didik. Bandung : Alfabeta

Depdiknas . (2003). Undang-undang RI No.20 tahun 2003.Tentang Sistem Pendidikan Nasional.

Dwi Atmanti, H. (2005). Investasi sumber daya manusia melalui pendidikan. Jurnal Dinamika Pembangunan (JDP), 2(Nomor 1), 30-39.

Elfachmi, Amin Kuneifi. (2016). Pengantar Pendidikan. Jakarta:PT Gelora Aksara Pratama.

Haryanto. (2012). Pengertian Pendidikan Karakter. [Online]. Tersedia di: http://belajarpsikologi.com/pengertian-pendidikan-karakter/. Diakses 29 januari 2021

Heidjrachman \& Husnan, Suad (Ed. 4). (1997). Manajemen Personalia. Yogyakarta: BPFE.

Khasinah, S. (2013). Hakikat manusia menurut pandangan islam dan Barat. JURNAL ILMIAH DIDAKTIKA: Media Ilmiah Pendidikan dan Pengajaran, 13(2).

Kurniawati, E., \& Bakhtiar, N. (2018). Manusia Menurut Konsep Al-Quran dan Sains. Journal of Natural Science and Integration, 1(1), 78-94.

Laksana, S. D. (2016). Integrasi Empat Pilar Pendidikan (UNESCO) Dan Tiga Pilar Pendidikan Islam. Al-Idarah: Jurnal Kependidikan Islam, 6(1).

Maisyarah, E., \& Firman, F. (2019). Media Permainan Ular Tangga, Motivasi Dan Hasil

Belajar Peserta Didik Di Sekolah Dasar. Jurnal Pendidikan, 4(1), 32-38.

Manan, Bagir. (2001). Menyongsong Fajar Otonomi Daerah. Yogyakarta: Pusat Studi Hukum Fakultas Hukum UII.

Marisyah, A., Firman, F., \& Rusdinal, R. (2019). Pemikiran Ki Hadjar Dewantara tentang Pendidikan. Jurnal Pendidikan Tambusai, 3(3), 1514-1519.

Mudyahardjo, Redja. (2012). Pengantar Pendidikan. Jakarta: PT. Raja Grafindo Persada.

Muthahhari, M. (2002). Manusia dan Alam Semesta. Jakarta: al-Huda.

Ningrum, E. (2016). Pengembangan sumber daya manusia bidang pendidikan. Jurnal Geografi Gea, 9(1).

Prayitno. (2009). Dasar Teori dan Praktis Pendidikan. Jakarta: Grasindo.

Rini, Y. S., \& Tari, J. P. S. (2013). Pendidikan: Hakekat, Tujuan, dan Proses. Jogyakarta: Pendidikan Dan Seni Universitas Negeri Jogyakarta.

Rumapea, M. E. (2015). Urgensi Pendidikan Karakter di Perguruan Tinggi. JUPIIS: Jurnal Pendidikan Ilmu-Ilmu Sosial, 7(1), 49-59.

Sahroni, D. (2017). Pentingnya pendidikan karakter dalam pembelajaran. In Prosiding Seminar Bimbingan Dan Konseling (Vol. 1, No. 1, pp. 115-124). 
Saihu, S. (2019). Konsep Manusia dan Implementasinya dalam Perumusan Tujuan Pendidikan Islam Menurut Murtadha Muthahhari. Andragogi: Jurnal Pendidikan Islam dan Manajemen Pendidikan Islam, 1(2), 197-217.

Suci, D. W., Firman, F., \& Neviyarni, N. (2019). Peningkatan Keterampilan Berpikir Kritis Siswa Melalui Pendekatan Realistik Di Sekolah Dasar. Jurnal Basicedu, 3(4), 20422049.

Sujana, I. W. C. (2019). Fungsi dan tujuan pendidikan Indonesia. Adi Widya: Jurnal Pendidikan Dasar, 4(1), 29-39.

Syarif, M. (2017). Hakekat Manusia dan Implikasinya Pada Pendidikan Islam. Jurnal Pendidikan Agama Islam Al-Thariqah, 2(2), 135-147.

Tirtarahardja, Umar \& S.L. La Sulo. (2010). Pengantar Pendidikan. Jakarta: PT Rineka Cipta. Undang-undang Republik Indonesia Nomor 39 Tahun 1999, Tentang Hak Asasi Manusia.

Usman, H. Suparman. (2008). Etika dan Tanggung Jawab Profesi Hukum di Indonesia. Jakarta: Gaya Media Pratama.

Wahyudin. (2008). Pengantar Pendidikan. Jakarta: Universitas Terbuka.

Zed, Mestika. (2008). Metode Penelitian Kepustakaan. Jakarta: Yayasan Obor Indonesia. 